\title{
sciendo
}

DOI: 10.2478/jolace-2021-0013

\section{Resilience of beginning and advanced teachers in managing various changes in their profession}

\author{
Beata Deutscherova \\ Tomas Bata University in Zlin, Czech Republic \\ b_deutscherova@utb.cz
}

\begin{abstract}
The paper is devoted to obtaining information on the resilience of kindergarten and primary school teachers. In the research, special attention was paid to beginning teachers, who we thought were more likely to be less resilient than teachers with longer experience. The research sample consisted of teachers of selected kindergartens and primary schools throughout the Czech Republic. The aim of the research was to find out whether there are differences in resilience between selected groups of teachers due to the current pandemic situation that each teacher had to deal with. Analysis of the data in the research revealed that beginning teachers have different rates of resilience compared to advanced teachers. No statistically significant differences were found in resilience between kindergarten and primary school teachers.
\end{abstract}

Keywords: teaching, resilience, dimension of resilience, beginning teacher, advanced teacher, teacher profession, teacher identity

\section{Introduction}

Teaching is a social category that is created and fixed in social activities. These activities include what takes place in the university, including the process of becoming a teacher. The concept of teaching is constructed by all people who have life experience with school education. However, for those who are teachers or are on their way to become teachers, the construction of a teacher's identity is constructed. According to Gavora and Wiegerova (2014), the construction of a teacher's professional identity is a continuous, permanent and unceasing process, with the most flexible period being the beginning of a teacher's professional career. In the first phase, a certain preconcept of the teacher is created, in childhood often realized in the form of teacher self-presentation (Gavora, 2002). Due to other situations (life, academic, professional), this preconcept deepens. Social and cognitive processes are not enough to construct an identity. One needs a certain emotional basis to be sensitive to social categories and to be involved in the construction process. Therefore, the affective side of the construction process is always important when creating a social category (Wiegerová \& Gavora, 2014). Resilience is based on those affective processes, but it is influenced by social factors.

The issue of coping with the requirements of the teaching profession is one of the current topics in pedagogy. Coping with the demands of the teaching profession can also be explored with an emphasis on rapid changes in the environment. Resilience is an abstract, difficult to define and complicated concept that has been explained differently over time. Beltman, Mansfield and Price (2011) state that resilience is a very complex and multifaceted concept, which is a difficult challenge to define. Day et al. $(2006,2007)$ draws attention to flexible lethality resilience. The authors (Greenberg, 2006; Luthar \& Brown, 2007) signal that resilience itself is based on both the regulation of emotions and the interaction between psychological, behavioral, and cognitive aspects of functioning. According to Luthar, Cicchetti, \& Becker (2003), resilience is defined as "a phenomenon 
that is influenced by individual circumstances, situations, and the environment and involves far more complex components."

Kyriacou (2010) states that resilience is understood as a process in which the teacher is able to maintain a positive attitude and at the same time resist the color palette of appeals, pressures and demands that belong to the normal work of the teacher. Resilience is not impossible to learn, it can be developed through abilities and skills such as communication, control of one's emotions, positive thinking, problem solving, developing effective relationships and the use of effective communication tactics in personal life and in the workplace. According to the authors (Gu \& Day, 2007; Howard \& Johnson, 2004; Tait, 2008), resilient teachers respond effectively and can effectively influence all students in a stressful environment of a classroom or school while achieving greater personal satisfaction that their work allows. Richards, Levesque-Bristol, Templin et al. conducted research in the United States in 2016 to examine the resilience of primary and secondary school teachers. Their research sample consisted of 415 teachers in 174 primary schools and 241 secondary schools. A shorter version of the CD-RISC questionnaire was used, namely a 10-question version. The result of their research was a finding that teachers who achieve a higher level of resilience are less emotionally exhausted, gain a greater sense of satisfaction from their work and are able to communicate positively with others. They can also manage their own education, for example in improving their language training. The research has also generally supported the notion that certain elements of the work environment can help to shape resilience, while others threaten teachers' resilience. One of the key conclusions of the research was that promoting resilience should be systematic, especially for beginning teachers. It is crucial to make the teachers understand the full scope of their responsibilities, including tasks, in which they do not work with children. The authors also mention that better preparation at the beginning of a career means preventing the burnout syndrome as well as possible leaving work.

The presented research discusses the degree of resilience of kindergarten and primary school teachers.

\section{Research survey methodology}

The aim of the research was to find out what resilience Czech kindergarten and primary school teachers have. The resilience of kindergarten and primary school teachers was measured by the Sense of Coherence questionnaire created by Antonovsky (1987). The Sense of Coherence questionnaire consisted of 29 items, which were divided into three dimensions: a) meaningfulness, b) manageability, c) comprehensibility. These three dimensions are based on the fact that when encountering stressors, one is motivated to manage the situation (meaningfulness), perceives the demands as comprehensible (comprehensibility), and feels that he has the resources to manage the situation (manageability).

Teachers were invited to fill in the questionnaire by e-mail and the questionnaire was available on a website created for our research. Emails inviting participants to fill in the questionnaires were sent out in the autumn of 2019. A total of 1,684 emails were sent, the questionnaire was filled in by 669 respondents, of which 476 were kindergarten teachers and 193 were primary school teachers. The questionnaire contained a seven-point scale with two opposing phrases. On this scale, respondents chose their answer. Sociographic data on respondents were also part of the questionnaire. There were five questions focusing on the length of professional experience, the highest education attained, age, job position, gender and in which region of the Czech Republic the respondent works. Research data were processed using the statistical program STATISTICA. The research 
results were analyzed using selected statistical methods. Methods of nonparametric statistics were used to verify the statistical significance of the differences, namely the Wilcoxon two-sample test and the Kruskal-Wallis test.

Resilience was observed between the above mentioned groups of teachers in each of the three dimensions. Based on the facts stated above, the following hypotheses were established in the research:

H1: Primary school teachers have a higher resilience than kindergarten teachers.

H2: Beginning teachers have a lower level of resilience compared to advanced teachers.

H3: Teachers with higher educational attainment have a higher rate of resilience than teachers with lower education.

\section{Interpretation of research findings}

To verify the correctness of the research hypothesis H1, we analyzed the answers of all teachers together, i.e. 669 teachers who work in both types of schools. Our aim was to find out whether the difference between the two groups of teachers is statistically significant in individual dimensions of resilience.

First, for comparison in both groups of teachers (kindergarten teachers and primary education teachers), we calculated selected basic statistical characteristics of the observed features - dimensions: comprehensibility, meaningfulness and manageability, which are clearly listed in Tables 1 to 3.

\begin{tabular}{|c|c|c|c|c|c|}
\hline School grade & $\begin{array}{c}\text { Arithm. average } \\
\text { (average score }\end{array}$ & $\mathbf{N}$ & $\begin{array}{c}\text { Direction. } \\
\text { Deviation }\end{array}$ & Min & Max \\
\hline 1 & 46.60 & 476 & 8.97 & 14.00 & 72.00 \\
\hline 2 & 46.68 & 193 & 8.74 & 22.00 & 67.00 \\
\hline total & 46.62 & 669 & 8.90 & 14.00 & 72.00 \\
\hline
\end{tabular}

Tab. 1: Results for the comprehensibility dimension

\begin{tabular}{|c|c|c|c|c|c|}
\hline School grade & $\begin{array}{c}\text { Arithm. average } \\
\text { (average score) }\end{array}$ & $\mathbf{N}$ & $\begin{array}{c}\text { Direction. } \\
\text { Deviation }\end{array}$ & Min & Max \\
\hline 1 & 44.58 & 476 & 6.34 & 18.00 & 56.00 \\
\hline 2 & 44.15 & 193 & 6.28 & 23.00 & 55.00 \\
\hline together & 44.46 & 669 & 6.32 & 18.00 & 56.00 \\
\hline
\end{tabular}

Tab. 2: Results for the meaningfulness dimension

\begin{tabular}{|c|c|c|c|c|c|}
\hline School grade & $\begin{array}{c}\text { Arithm. average } \\
\text { (average score) }\end{array}$ & $\mathbf{N}$ & $\begin{array}{c}\text { Direction. } \\
\text { Deviation }\end{array}$ & Min & Max \\
\hline 1 & 49.29 & 476 & 8.09 & 17.00 & 69.00 \\
\hline 2 & 49.19 & 193 & 7.95 & 26.00 & 64.00 \\
\hline together & 49.26 & 669 & 8.04 & 17.00 & 69.00 \\
\hline
\end{tabular}

Tab. 3: Results for the manageability dimension 
Looking at the Tables 1 to 3, we can see that there are only small differences between the two groups of teachers in the average values of the observed scores in each dimension. However, we were interested in whether these differences are also statistically significant. Wilcoxon's two-sample test was used to verify the statistical significance of the differences between the two groups of teachers (created according to the level of school they work in) in the 3 observed characters (comprehensibility, meaningfulness and manageability).

The test results were evaluated based on the $\mathrm{p}$ value.

\begin{tabular}{|c|c|c|}
\hline variable & $\boldsymbol{Z}$ & $\boldsymbol{p}$-value \\
\hline comprehensibility & -0.459 & 0.646 \\
\hline meaningfulness & 0.424 & 0.671 \\
\hline manageability & -0.097 & 0.923 \\
\hline
\end{tabular}

Tab. 4: Mann-Whitney test results

Based on the results shown in Table 4, it can be seen that the value of the probability $p$ is greater than 0.05 in all three cases. This means that kindergarten teachers did not achieve statistically significant results in any dimension compared to primary school teachers. In contrast to our expectations, the resilience of primary school teachers did not prove to be higher and the validity of hypothesis $\mathrm{H} 1$ was thus not confirmed. Teacher resilience in our research does not depend on the type of school in which teachers work.

We were also interested in whether resilience varies according to the length of professional experience. We were especially interested in beginning teachers. The research group was divided into 4 subgroups of teachers, created according to the length of practise, with the first group consisting of beginning teachers (127). This group included teachers who have had experience of a maximum of 3 years. The second group (215) consisted of teachers with experience of 3 - 10 years. The third group (125) then consisted of teachers with a professional experience from 11 to 20 years. In the last, fourth group (202), were teachers with more than 21 years of experience. The Kruskal - Wallis test was used to verify the statistical significance of the differences between the 4 groups of teachers in the observed characters.

A statistically significant difference was found in this case, especially in the first dimension, i.e. in the dimension that indicates how motivated the teacher is to manage a stressful situation. Teachers with a high score in this dimension are expected to be strongly motivated to cope with any stressful situation in which they might find themselves in the future.

\begin{tabular}{|l|c|c|c|c|}
\hline & 1.group $(0,3>$ & 2.group $(3,10>$ & 3.group $(10,20>$ & 4.group nad 20 \\
\hline 1. group $[0.3>$ & & $0.007^{*}$ & $0.000^{*}$ & $0.000^{*}$ \\
\hline 2. group $(3.10>$ & & & 0.669 & $0.002^{*}$ \\
\hline 3. group $(10.20>$ & & & & 0.771 \\
\hline
\end{tabular}

Tab. 5: Results of the Kruskal-Wallis multiple comparison test (p-values)

It is clear from Table 5 that there is a statistically significant difference between beginning teachers and groups of teachers with experience. Statistical data processing revealed that the length of a teacher's professional experience affects his ability to cope 
with stressful situations in the future. A teacher whose score is high in this dimension has a presumption that he will also be motivated to overcome the obstacles he encounters.

A similar finding was confirmed in the other two dimensions. This means that beginning teachers have a lower level of resilience than advanced teachers. The second hypothesis was therefore confirmed.

We were also interested in whether resilience varies according to the level of education. The research group was divided into 4 subgroups of teachers, with the first group consisting of teachers with secondary education (214). The second group (50) consisted of teachers with higher professional education. The third group (159) consisted of teachers with a bachelor's degree. The last, fourth group, (246) consisted of teachers with a master's degree. In this case, too, the Kruskal-Wallis test performed using the STATISTICA program was used. After entering the input data in the computer output report, the following results were obtained for the selected character comprehensibility, meaningfulness and manageability (Tab.6)

\begin{tabular}{|c|c|c|}
\hline & $H$ & $p$ \\
\hline comprehensibility & 5.183 & 0.159 \\
\hline meaningfulness & 3.819 & 0.282 \\
\hline manageability & 1.152 & 0.764 \\
\hline
\end{tabular}

Tab. 6: Results of Kruskal - Wallis test (level of education)

Based on the values given in Table 6, we can see that the calculated value of the probability $p$ is in all three cases greater than 0.05 , which means that we cannot reject the null hypothesis. That is the difference between 4 groups of teachers (according to the level of education) with respect to each observed trait, more precisely for each dimension: comprehensibility, meaningfulness and manageability, are not statistically significant. This means that teachers in all 4 groups (according to level of education) achieved almost the same score in each dimension. The test did not confirm the validity of hypothesis H3.

\section{Conclusion and discussion}

Research into the resilience of kindergarten and primary school teachers is quite unique in the Czech Republic. Although kindergarten teachers declare low resilience in the research, they are interested in changing the situation. The proof is the gradually increasing resilience of teachers (Paulík, 2011). Looking beyond our borders, teacher resilience is a topical issue (Crane \& Searle, 2016; Mansfield, Beltman, Broadley, \& Weatherby-Fell, 2016; Worsley, 2015).

Teacher resilience is repeatedly discussed by both Czech and foreign researchers, and this study also confirms the need to pay increased attention to this issue.

Therefore, the paper dealt with the resilience of kindergarten and primary school teachers. The theoretical part focused on defining resilience and research concerning resilience.

The aim of the research was to determine the degree of resilience of kindergarten teachers and primary school teachers. The Sense of Coherence questionnaire, authored by Antonovsky, was used to obtain as much data as possible. This research was conducted with 669 respondents. The questionnaire was administered online.

It was found that there were no statistically significant differences in resilience between kindergarten and primary school teachers, not even in the area of educational attainment. Beginning teachers were proved to have a lower resilience rate than advanced 
teachers. These results can be compared with the research of $\mathrm{Gu}$ and Day (2013), Hoffenbartal and Bocos (2015) and others. An explanation of these findings can be found in Antonovsky's theory (1998), in which he emphasized that various kinds of experience during a person's life would lead to the development of SOC.

The conclusions of this study emphasize the importance of the role of initial teacher education in the context of the previously neglected development of resilience, which is important not only in terms of lasting effectiveness, but also the professional growth of teachers. In terms of further research, it is therefore necessary to examine how teachers of future teachers implement approaches to increasing resilience in study programs. It can be an opportunity for future teachers to respond to training in resilience, burnout and the leave of beginning teachers. These recommendations can then have a significant impact on the resilience of both beginning teachers and student teachers.

\section{Acknowledgments}

The contribution was created as a part of the project IGA / FHS / 2019/003.

\section{References}

Beltman, S., Mansfield, C., \& Price, A. (2011). Thriving not just surviving: A review of research on teacher resilience. Educational Research Review, 6(3), 185-207. DOI: https://doi.org/10.1016/j.edurev.2011.09.001

Day, C. (2008). Committed for life? Variations in teachers' work, lives and effecti-veness. Journal of Educational Change, 9(3), 243-260.

Day, C., \& Gu, Q. (2007). Variations in the conditions for teachers' professional lear-ning and development: Sustaining commitment and effectiveness over a career. Oxford Review of Education, 33(4), 423-443. DOI: https://doi.org/10.1080/03054980701450746

Day, C., \& Gu, Q. (2014). Resilient Teachers, Resilient Schools. London: Routledge. DOI: https://doi.org/10.4324/9780203578490

Day, C., Sammons, P., Stobart, G., Kington, A., \& Gu, Q. (2007). Teachers matter: Connecting lives, work and effectiveness.Maidenhead, Open University Press.

Day, C., Stobart, G., Sammons, P., Kington, A., Gu, Q., \& Smees, R. (2006). Variation in teachers' work, lives and effectiveness. London: DfES.

Deutscherová, B. (2020). Resilience učitelů mateřských škol a 1. stupně základních škol [Rigorózní práce]. Zlín: Univerzita Tomáše Bati ve Zlíně.

Gavora, P. (2002). Rozhodnutie stat' sa učitel'om - pohl'ad kvalitatívneho výskumu. Pedagogická revue, 54(3), 240-256.

Greenberg, M. T. (2006). Promoting Resilience in Children and Youth: Preventive Interventions and Their Interface with Neuroscience. Annals Of The New York Aca-demy Of Sciences, 1094(1), 139-150. DOI: 10.1196/annals.1376.013

Gu, Q., \& Day, C. (2007). Teachers resilience: A necessary condition for effective-ness. Teaching And Teacher Education, 23(8), 1302-1316. DOI: https://doi.org/10.1016/j.tate.2006.06.006

$\mathrm{Gu}$, Q., \& Day, C. (2013). Challenges to Teacher Resilience: Conditions Count. British Educational Research Journal, 39, 22-44.

Gu, Q., \& Day, C. (2013). Challenges to Teacher Resilience: Conditions Count. British Educational Research Journal, 39, 22-44. DOI: https://doi.org/10.1080/01411926.2011.623152 
$\mathrm{Gu}$, Q., \& Li, Q. (2013). Sustaining resilience in times of change: Stories from Chinese teachers. Asia-Pacific Journal of Teacher Education, 41(3), 288-303. DOI: 10.1080/1359866X.2013.809056

Hoffenbartal, D., \& Bocos, M. (2015). The Development of a Sense of Coherence in Teaching Situations among Special Education Pre-service Teachers. Procedia - Social and Behavioral Sciences, 209, 240-246. DOI: https://doi.org/10.1016/j.sbspro.2015.11.225

Howard, S., \& Johnson, B. (2004). Resilient teachers: resisting stress and bur-nout. Social Psychology Of Education, 7(4), 399-420. DOI: 10.1007/s11218-004-0975-0

Kyriacou, C. (2010). Teacher Stress: Directions for future research. Educational Review, 53(1), 27-35. DOI: https://doi.org/10.1080/00131910120033628

Luthar, S. S. \& Brown, P. J. (2007). Maximizing resilience through diverse levels of inquiry: Prevailing paradigms, possibilities, and priorities for the future. Development And Psychopathology, 19(3), 931-955. DOI: 10.1017/S0954579407000454

Luthar, S. S., Cicchetti, D., \& Becker, B. (2003). The Construct of Resilience: A Critical Evaluation and Guidelines for Future Work. Child Development, 71(3), 543562. DOI: $10.1111 / 1467-8624.00164$

Markechová, D., Stehlíková, B., \& Tirpáková, A. (1990). Štatistické metódy a ich aplikácie. Nitra, UKF.

Tait, M. (2008). Resilience as a Contributor to Novice Teacher Success, Commitment, and Retention. Teacher Education Quarterly, 35, 57-76.

Wiegerová, A., \& Gavora, P. (2014). Proč se chci stát učitelkou v mateřské škole? Pohled kvalitativního výzkumu. Pedagogická Orientace, 24(4), 510-534.

\section{Contact}

PhDr. Beata Deutscherova, MBA,

Tomas Bata University in Zlin

Faculty of Humanities

Department of School Pedagogy

Štefanikova 5670

76001 Zlin

Czech Republic

b_deutscherova@utb.cz 